Sains Malaysiana 49(5)(2020): 995-1002

http://dx.doi.org/10.17576/jsm-2020-4905-04

\title{
Optimization of Cinnamaldehyde Extraction and Antioxidant Activity of Ceylon Cinnamon Extract
}

\author{
(Pengoptimuman Pengesktrakan Sinamaldehid dan Aktiviti Antioksidan Ekstrak Kulit Kayu Manis Ceylon)
}

\author{
ZetTy ShafiQA Othman, Mohamad Yusof MASKAT \& NUR HASYAREEDA HASSAN*
}

\begin{abstract}
Cinnamon is a spice obtained from the inner bark of cinnamomum tree. Cinnamaldehyde, the major consitituent of the cinnamon essential oil is responsible for the flavor and aroma of whole cinnamon. Cinnamaldehyde have various medicinal application including neuroprotection. Thus, this study intends to identify the optimal condition for cinnamaldehyde extraction with high antioxidant activity of cinnamon extract. Responses (cinnamaldehyde yield, TPC, and TEAC) were optimized using response surface methodology (RSM) by employing two factors (temperature and extraction time) based on a three level face centered central composite design (CCD). Level of extraction temperature used were $30^{\circ} \mathrm{C}, 55^{\circ} \mathrm{C}$ and $80^{\circ} \mathrm{C}$, while extraction time were 4,7 , and $10 \mathrm{~h}$. The CCD consisted of 8 experimental point and 5 replicates of central points. The optimal conditions to obtain maximum cinnamaldehyde yield, TPC and TEAC were extraction temperature of $37^{\circ} \mathrm{C}$ at $5 \mathrm{~h}$ extraction time with predicted cinnamaldehyde yield of $3.05 \mathrm{mg} / \mathrm{g}$, TPC of $682.17 \mathrm{mg}$ GAE/ $\mathrm{g}$ and TEAC of $821.57 \mu \mathrm{mol} \mathrm{TE} / \mathrm{g}$ respectively. The experimental values obtained for the cinnamaldehyde yield, TPC, and TEAC under the optimal condition were $3.11 \pm 0.71 \mathrm{mg} / \mathrm{g}, 682.66 \pm 54.85 \mathrm{mg} \mathrm{GAE} / \mathrm{g}$, and $817.89 \pm 9.03 \mu \mathrm{mol} \mathrm{TE} / \mathrm{g}$. The proximity between experimental and prediction values verify the fitness of RSM models applied for determination of optimal condition for cinnamaldehyde extraction.
\end{abstract}

Keywords: Antioxidant; cinnamon; cinnamaldehyde; optimization; RSM

ABSTRAK

Kayu manis adalah rempah yang diperoleh daripada kulit dalaman pokok daripada tumbuhan Cinnamomum. Sinamaldehid, adalah sebatian utama minyak pati kayu manis yang bertanggungjawab untuk rasa dan aroma keseluruhan kayu manis. Sinamaldehid mempunyai pelbagai aplikasi dalam perubatan termasuklah perlindungan dihedlamanis nakartskegnep igab mumitpo naadaek itsap lanegnem kutnu naujutreb ini naijak, uti helO .oruendengan aktiviti antioksidan ekstrak kayu manis yang tinggi. Respons (hasil sinamaldehid, TPC dan TEAC) telah dioptimumkan menggunakan kaedah tindak balas permukaan (RSM) dengan mengaplikasikan dua faktor (suhu dan masa pengekstrakan) berdasarkan tiga tahap reka bentuk komposit berpusat (CCD) berpusat muka. Aras suhu pengekstrakan yang digunakan adalah $30^{\circ} \mathrm{C}, 55^{\circ} \mathrm{C}$ dan $80^{\circ} \mathrm{C}$, manakala masa pengekstrakan adalah 4,7 dan 10 jam. CCD adalah terdiri daripada 8 titik uji kaji dan 5 ulangan titik pusat. Keadaan optimum untuk memperoleh hasil sinamaldehid TPC dan TEAC maksimum adalah suhu pengekstrakan $37{ }^{\circ} \mathrm{C}$ pada 5 jam masa pengekstrakan dengan hasil sinamaldehid diramalkan $3.05 \mathrm{mg} / \mathrm{g}, 682.17 \mathrm{mg}$ GAE/ $\mathrm{g}$ TPC dan $821.57 \mu \mathrm{mol}$ TE/g TEAC. Nilai uji kaji yang diperoleh bagi hasil sinamaldehid, TPC dan TEAC pada keadaan optimum adalah $3.11 \pm 0.71 \mathrm{mg} / \mathrm{mL}, 682.66 \pm 54.85 \mathrm{mg} \mathrm{GAE} / \mathrm{g}$ dan 817.89 $\pm 9.03 \mu \mathrm{mol}$ TE/g. Kehampiran antara nilai uji kaji dan ramalan mengesahkan kesesuaian model RSM yang digunakan bagi penentuan keadaan optimum pengekstrakan sinamaldehid.

Kata kunci: Antioksidan; kayu manis; pengoptimuman; RSM; sinamaldehid

\section{INTRODUCTION}

Cinnamon has been used for centuries as spice with several pharmacological benefits due to the presence of polyphenolic constituent including phenolic acids, coumarin proanthocyanidin besides volatile essential oils (Momtaz et al. 2018; Wang et al. 2013). Cinnamon therapeutic application also corresponds to its antioxidant, anti-inflammatory, anti-fungal, anti-mutagenic and anticarcinogenic properties (Jayaprakasha et al. 2007;
Mathew et al. 2006). Cinnamaldehyde is the main compound of the volatile oils which contribute to the aromatic smell of cinnamon. Besides its antimicrobial, antioxidant, antitumor bioactivity, cinnamaldehyde was reported to aid as neuroprotection due to its potential in inhibiting tau protein aggregation, the hallmark of Alzheimer's disease (AD) (Momtaz et al. 2018; Peterson et al. 2009; Singletary 2008). Thus, optimization of cinnamaldehyde extraction would greatly influence its usage in pharmaceutical application towards AD treatments. Response surface methodology 
(RSM) can be used as an optimization method which optimize a process when several factors affect a targeted response (Zhen et al. 2008). RSM comprises mathematical and statistical techniques based on a polynomial equation that best fits experimental data in order to describe the behavior of the data set with the objective of projecting statistical predictions (Rafi et al. 2015). Several studies have been reported on the optimization of cinnamon and cinnamaldehyde extraction (Dvorackova et al. 2015; Lee et al. 2018; Nandam et al.2012; Wardatun et al. 2017) and studies by Suryanti et al. (2018) reported moderate antioxidant activity of cinnamaldehyde with $\mathrm{IC}_{50}$ of 95.38 . However, correlation between the yield of cinnamaldehyde with antioxidant activity of cinnamon extract has yet to be reported. Therefore, this study aimed to determine the optimal condition for cinnamaldehyde extraction and antioxidant activity of cinnamon extract.

\section{MATERIALS AND METHODS}

\section{CINNAMON EXTRACTION}

Ceylon cinnamon purchased from Sri Lanka was ground to a particle size of $0.5 \mathrm{~mm}$. The maceration extraction of cinnamon was carried out using $95 \%(\mathrm{v} / \mathrm{v})$ ethanol (Wardatun et al. 2017) at a solvent to solid mass of 10 $\mathrm{mL} / \mathrm{g}$ at $80^{\circ} \mathrm{C}$ for exhaustive extraction time determination (Dvorackova et al. 2015). For optimizing, various temperature and extraction time according to design of experiment were applied for cinnamon extraction (Table 1).

\section{QUANTIFICATION OF CINNAMALDEHYDE YIELD USING RP-HPLC}

Reversed phase- high performance liquid chromatography (RP-HPLC) was used to quantify the yield of cinnamaldehyde extracted through external standard calibration. The conditional parameters involved in the RP-HPLC were as follows: $0.8 \mathrm{~mL} / \mathrm{min}$ flow rate; injection volume of $20 \mu \mathrm{L}$; mobile phase of acetonitrile and deionized water with a ratio of $60: 40$; temperature of 40 ${ }^{\circ} \mathrm{C}$ and (5) photodiode array detector (PDA) wavelength at $280 \mathrm{~nm}$ (Jiao et al. 2013).

\section{OPTIMIZATION USING RESPONSE SURFACE METHODOLOGY} (RSM)

Response surface methodology was used to predict the optimize conditions for cinnamaldehyde extraction based on cinnamaldehyde yield, TPC and TEAC. Thirteen experimental trial were randomly run per Central Composite Design (CCD) with independent variables consisting of temperature $\left(\mathrm{X}_{1}: 30{ }^{\circ} \mathrm{C}, 55^{\circ} \mathrm{C}, 80{ }^{\circ} \mathrm{C}\right)$ and extraction time $\left(\mathrm{X}_{2}: 4 \mathrm{~h}, 7 \mathrm{~h}, 10 \mathrm{~h}\right)$ employed at three equidistant levels $(-1,0,+1)$.

\section{TOTAL PHENOLIC CONTENT (TPC) AND TROLOX EQUIVALENT ANTIOXIDANT CAPACITY (TEAC)}

The total phenolic content of extracts was determined using the Folin-Ciocalteu Calorimetric method according to Sembiring et al. (2018) and Yang et al. (2012) with modification. $20 \mu \mathrm{L}$ diluted samples $(1 \mathrm{mg} / \mathrm{mL})$ were placed in microplate wells. Subsequently $100 \mu \mathrm{L}$ of Folin Ciocalteu $(10 \%, \mathrm{v} / \mathrm{v})$ was added. Mixture was left incubated in dark at ambient temperature for $10 \mathrm{~min}$. Then, $80 \mu \mathrm{L} \mathrm{Na}_{2} \mathrm{CO}_{3}$ (7.5\%) been added. The mixtures were shake and left in dark for $2 \mathrm{~h}$ and the absorbance was measured at $765 \mathrm{~nm}$. Total phenolic content was assessed by plotting the gallic acid calibration curve $(\mathrm{Y}=0.0032 \mathrm{X}+0.9436)$ and expressed as milligrams of gallic acid equivalents (GAE) per grams of dried extract. While DPPH scavenging ability assay was used to evaluate the antioxidant activity of each extract with Trolox as standard. Test was conducted in a 96-well plate where $100 \mu \mathrm{L}$ of samples extract and $100 \mu \mathrm{L}$ of DPPH solution $0.2 \mathrm{mM}$ were added to each well. After $30 \mathrm{~min}$ incubation at room temperature in dark room, absorbance was read at $517 \mathrm{~nm}$ using micro-plate reader. The DPPH radical scavenging (\%) of samples were calculated using (1). Antioxidant capability of the extracts would be expressed based on Trolox equivalent antioxidant capacity (TEAC) in the unit of $\mu \mathrm{mol} \mathrm{TE} / \mathrm{g}$. TEAC of samples were calculated based on calibration curve $(\mathrm{Y}=$ $35.987 \mathrm{X}+38.67)$ of Trolox DPPH scavenging activity (\%) against log series dilution concentration plot.

$$
\% \text { DPPH Scavenging }=\left[\frac{A_{D P P H}-A_{\text {Sample }}}{A_{D P P H}}\right] \times 100 \text { (1) }
$$

\section{VERIFICATION OF OPTIMUM PREDICTED AND EXPERIMENTAL DATA}

After determination of optimum condition with predicted cinnamaldehyde yield, TPC and TEAC values, experimental was done in triplicate for optimum condition validation. Validation was done through Root Mean Squared Deviation (RMSD) (Haslaniza et al. 2013; Pineiro et al. 2008) using the following formula:

$$
R M S D=\sqrt{\frac{1}{n-1} \sum_{i=1}\left(\widetilde{y}_{i}-y_{i}\right)^{2}}
$$

where $\breve{y}_{i}$ is the Observed value, and $y_{i}$ is the Predicted value.

\section{RESULTS AND DISCUSSION}

\section{DETERMINATION OF EXHAUSTIVE TIME EXTRACTION}

Figure 1 shows the effect of extraction time on the yield of cinnamaldehyde. The yield of cinnamaldehyde increased significantly $(p<0.05)$ with an increase in extraction time from 2 to $4 \mathrm{~h}$. However, there was no significant change in the cinnamaldehyde yield at consecutive increase of extraction time up to $10 \mathrm{~h}$. The yield of cinnamaldehyde started to decline significantly $(p<0.05)$ from 12 to 24 $\mathrm{h}$ extraction time. The decline in cinnamaldehyde yield was due to the volatile properties of cinnamaldehyde as extraction time increased besides the high temperature 
which enhance the loss of cinnamaldehyde (Kim 2017). Therefore, for optimization, the range of extraction time used were from 4 to $10 \mathrm{~h}$.

\section{DETERMINATION OF OPTIMUM CONDITION FOR CINNAMALDEHYDE EXTRACTION}

Multiple linear regression results and analysis of the adequacy of the fitted model

Face centered composite design RSM with independent variables consisting of temperature $\left(\mathrm{A}: 30{ }^{\circ} \mathrm{C}, 55^{\circ} \mathrm{C}, 80\right.$ ${ }^{\circ} \mathrm{C}$ ) and extraction time (B: $\left.4 \mathrm{~h}, 7 \mathrm{~h}, 10 \mathrm{~h}\right)$ employed at three equidistant levels $(-1,0,+1)$ was used to acquire optimal condition for cinnamaldehyde extraction accompany with high TPC and TEAC. According to Table 1, the yield of cinnamaldehyde obtained from 13 experimental runs ranged from $2.48 \mathrm{mg} / \mathrm{g}$ to $3.27 \mathrm{mg} / \mathrm{g}$. Meanwhile, the TPC and TEAC ranged from $570.40 \mathrm{mg}$ $\mathrm{GAE} / \mathrm{g}$ to $686.44 \mathrm{mg} \mathrm{GAE} / \mathrm{g}$, and $772.31 \mu \mathrm{mol} \mathrm{TE} / \mathrm{g}$ to $826.14 \mu \mathrm{mol} \mathrm{TE} / \mathrm{g}$, respectively. Multiple regression analysis suggested that cinnamaldehyde yield (CY) response fit quadratic polynomial equation, while both TPC and TEAC responses fit linear equation (Table 2).

The fitness of the model can be determined based on the Lack-of-fit test (Khuri \& Cornell 2018) and $\mathrm{R}^{2}$. From the variance analysis (Table 2 ), all responses have significant model $(p<0.05)$ and non-significant the Lack-of-fit test $(p>0.05)$ accompanied with $\mathrm{R}^{2}$ for all model higher than 0.75 (Haslaniza et al. 2013) indicating a good fit of model. The $\mathrm{R}^{2}$ values for $\mathrm{CY}$, TPC, and TEAC were 0.9981, 0.8576, and 0.8174. The reasonable agreement between predicted $\mathrm{R}^{2}$ and adjusted $\mathrm{R}^{2}$ confirmed the fitness of all model for determination of optimal condition for cinnamaldehyde extraction (Table 2).

\section{EFFECTS OF TEMPERATURE AND EXTRACTION TIME ON CINNAMALDEHYDE YIELD, TPC, AND TEAC}

The ANOVA results demonstrated that both extraction parameters, temperature $\left(\mathrm{X}_{1}\right)$ and extraction time $\left(\mathrm{X}_{2}\right)$ were verified to be significant $(p<0.05)$ for $\mathrm{CY}$, TPC, and TEAC (Table 3). The coefficient for independent variables, temperature, ${ }^{\circ} \mathrm{C}\left(\mathrm{X}_{1}\right)$ and extraction time, hours $\left(\mathrm{X}_{2}\right)$ were in negative values implying that cinnamaldehyde yield, TPC and TEAC decreased with an increase in temperature and extraction time. Cinnamaldehyde is a volatile constituent of ceylon cinnamon essential oil. Thus, due to its volatile properties, at high temperature and prolonged extraction time reduction in cinnamaldehyde yield was observed (Kim 2017).

Cinnamon extract contains polyphenolic constituents which responsible for the antioxidant properties of the extract (Momtaz et al. 2018). The antioxidant properties of cinnamon extracts were represented by TPC and TEAC. Negative coefficient showed the declination of TPC and TEAC with an increase in temperature and extraction time. This occurrence is due to thermal degradation of polyphenols at prolonged extraction time at high temperature (Baba et al. 2016; Kim et al. 2018).

\section{INTERACTION BETWEEN EXTRACTION TEMPERATURE AND TIME TOWARDS CINNAMALDEHYDE YIELD}

ANOVA results showed the interaction between independent factors toward cinnamaldehyde yield but none for TPC and TEAC as the two responses fit linear equation. Three-dimensional (3D) response surface plot was developed to understand the interaction effects of the independent factors on the yield of cinnamaldehyde. The interaction variables model coefficient for cinnamaldehyde yield (CY) showed significance $(p<0.05)$ for $X_{11}, X_{22}, X_{12}$ which all in negative values. Figure 2(a) shows the response surface for interaction between temperature and extraction time with cinnamaldehyde yield. From Figure 2(a), it can be observed that cinnamaldehyde yield increase with increment in extraction time up to optimum point at each temperature. According to Abed et al. (2015) increase in temperature aid towards an increment in both diffusion coefficient and the solubility of cinnamaldehyde in ethanol, thus producing higher yield of cinnamaldehyde. Subsequently further increase in extraction time and temperature showed declination in cinnamaldehyde yield. Cinnamaldehyde is the major substituent in cinnamon bark oil (Utchariyakiat et al. 2016) which is volatile. Due to its volatile properties, prolonged in the extraction time at higher temperature above optimum point causes declination in cinnamaldehyde yield (Ashakirin et al. 2017; Kim 2017). In addition, previous study also reported that cinnamaldehyde posses volatile and thermolabile characteristics and extraction yield of these compounds was inversely proportional to the extraction temperature and time (Kim et al. 2017).

\section{CORRELATION BETWEEN CINNAMALDEHYDE YIELD, TPC AND TEAC}

According to Table 1, it can be observed that at the highest cinnamaldehyde yield of $3.27 \mathrm{mg} / \mathrm{g}$, TPC, and TEAC were moderate with the reading of $638.78 \mathrm{mg}$ $\mathrm{GAE} / \mathrm{g}$, and $789.55 \mu \mathrm{mol} \mathrm{TE} / \mathrm{g}$, respectively. Meanwhile, cinnamaldehyde yield is lower at the highest TPC and TEAC of $686.44 \mathrm{mg} \mathrm{GAE} / \mathrm{g}$, and $826.14 \mu \mathrm{mol} \mathrm{TE} / \mathrm{g}$ with a reading of $2.84 \mathrm{mg} / \mathrm{g}$. Although cinnamaldehyde have moderate antioxidant activity (Suryanti et al. 2018), output from Table 1 shows that antioxidant activity of cinnamon extract does not majorly influence by cinnamaldehyde yield but correlate with TPC as can be observed that, when TPC increases, TEAC also increased. This is in agreement with Momtaz et al. (2018) finding which reported that polyphenolic constituents in cinnamon extracts were responsible for the antioxidant properties of the extract. Even though, the correlation between cinnamaldehyde yield and antioxidant activity was not observed, optimizing the extraction condition is 
important prior to enhancing cinnamaldehyde yield and antioxidant capacity of cinnamon extracts simultaneously.

\section{OPTIMIZATION OF EXTRACTION CONDITION}

The optimal condition (Table 4) for cinnamaldehyde extraction with maximum TPC, and TEAC were $37{ }^{\circ} \mathrm{C}$ at $5 \mathrm{~h}$ extraction time with predicted cinnamaldehyde yield of $3.05 \mathrm{mg} / \mathrm{g}$, TPC of $682.17 \mathrm{mg} \mathrm{GAE} / \mathrm{g}$, and TEAC of $821.57 \mu \mathrm{mol} \mathrm{TE} / \mathrm{g}$, respectively. Meanwhile, the experimental verification obtained for the cinnamaldehyde yield, TPC, and TEAC under the optimal condition were $3.11 \pm 0.71 \mathrm{mg} / \mathrm{g}, 682.66 \pm 54.85 \mathrm{mg}$ $\mathrm{GAE} / \mathrm{g}$ and $817.89 \pm 9.03 \mu \mathrm{mol} \mathrm{TE} / \mathrm{g}$, respectively. The root mean square deviation (RMSD) for all responses were $0.03,0.17$, and 0.54 , respectively. Small values of RMSD proven the proximity between predicted and verified values, which implies the all model were fit and can be use to determine optimal condition for cinnamaldehyde extraction with high antioxidant capacity.

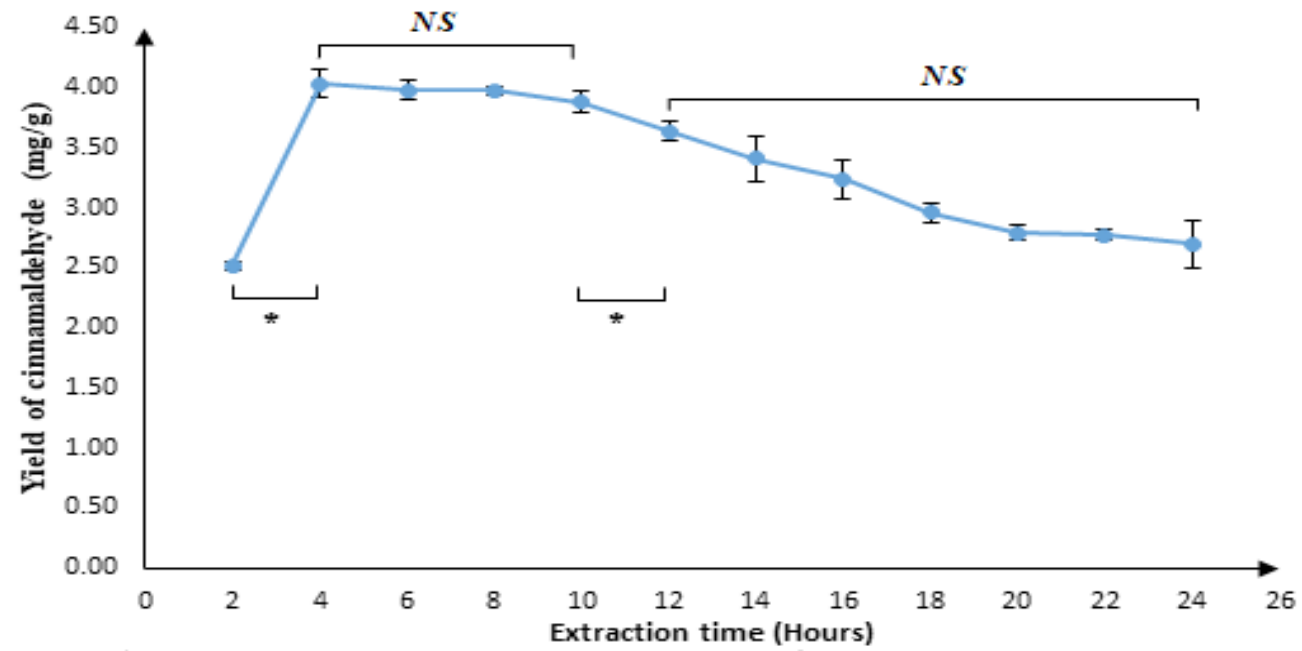

FIGURE 1. Cinnamaldehyde exhaustive extraction time (NS (non-significant): $p>0.05)$ and $* p$ $<0.05$ (significant)

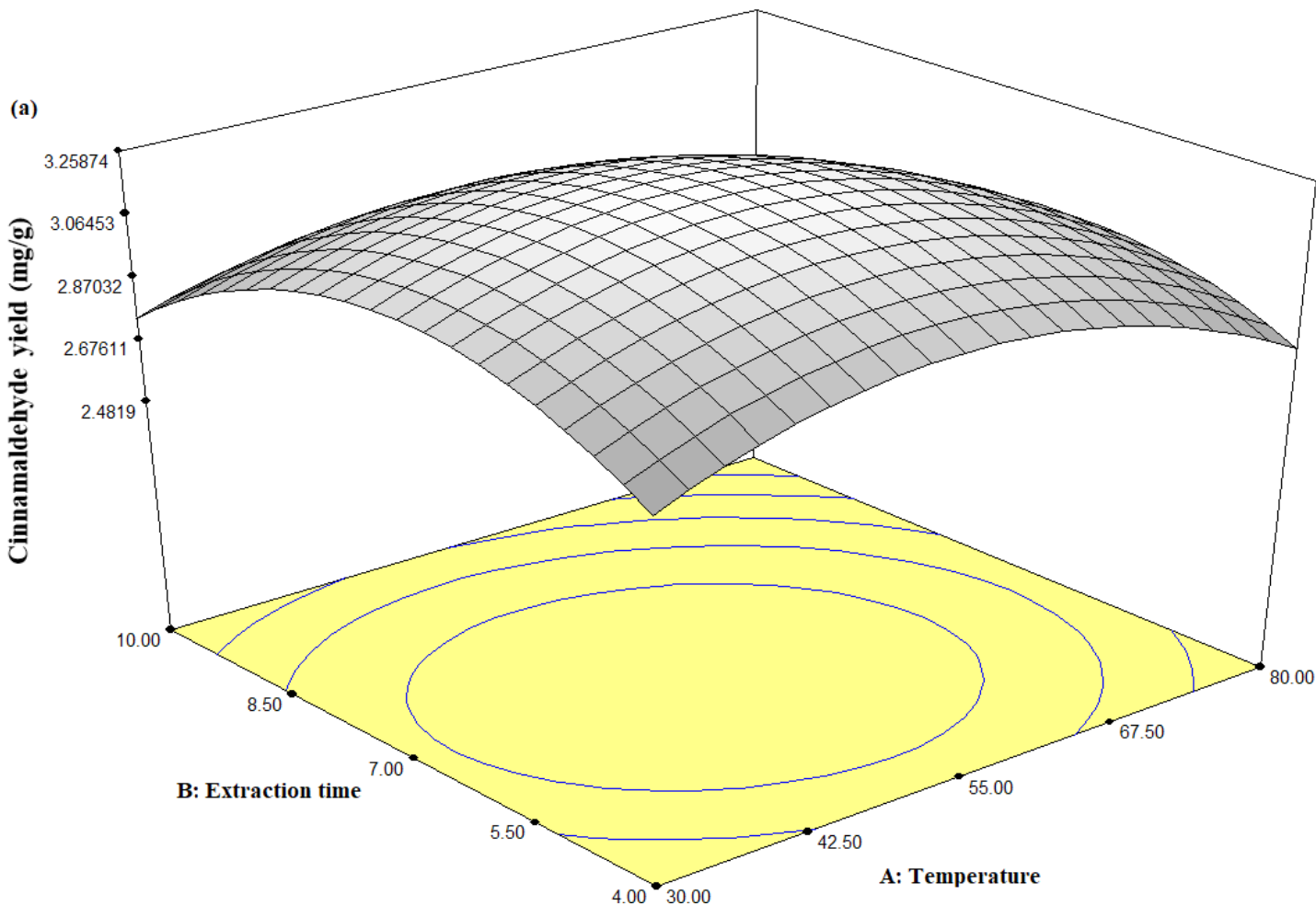

FIGURE 2. 3-Dimensional surface of (a) cinnamaldehyde yield as a function of temperature $\left({ }^{\circ} \mathrm{C}\right)$ and extraction time $(\mathrm{h})$ 
TABLE 1. Two-independent variable and three dependent variables, three-level face-centered central composite design

\begin{tabular}{|c|c|c|c|c|c|c|c|}
\hline \multirow{5}{*}{ Run } & \multicolumn{7}{|c|}{ RSM } \\
\hline & \multicolumn{4}{|c|}{ Independent variables } & \multicolumn{2}{|c|}{ Dependent variables } & \multirow{4}{*}{$\begin{array}{c}\mathrm{Y}_{3}: \\
\text { TEAC } \\
(\mu \mathrm{mol} \mathrm{TE} / \mathrm{g})\end{array}$} \\
\hline & & & & & $\mathrm{Y}_{1}:$ & $\mathrm{Y}_{2}:$ & \\
\hline & \multicolumn{2}{|c|}{ Temperature $\left({ }^{\circ} \mathrm{C}\right)$} & \multicolumn{2}{|c|}{$\begin{array}{l}\text { Extraction time } \\
\text { (h) }\end{array}$} & \multirow[t]{2}{*}{$\begin{array}{l}\text { cinnamaldehyde } \\
\text { yield }(\mathrm{mg} / \mathrm{g})\end{array}$} & \multirow[t]{2}{*}{$\begin{array}{c}\text { TPC } \\
\text { (mg GAE/g) }\end{array}$} & \\
\hline & actual & coded & actual & coded & & & \\
\hline 1 & 55 & 0 & 7 & 0 & $3.27 \pm 0.01$ & $638.78 \pm 22.32$ & $789.55 \pm 66.82$ \\
\hline 2 & 55 & 0 & 4 & -1 & $3.04 \pm 0.06$ & $670.40 \pm 12.89$ & $819.09 \pm 4.96$ \\
\hline 3 & 30 & -1 & 4 & -1 & $2.84 \pm 0.02$ & $686.44 \pm 0.00$ & $826.14 \pm 5.00$ \\
\hline 4 & 55 & 0 & 10 & 1 & $2.87 \pm 0.01$ & $570.40 \pm 55.20$ & $772.31 \pm 51.38$ \\
\hline 5 & 55 & 0 & 7 & 0 & $3.23 \pm 0.00$ & $631.13 \pm 3.54$ & $788.17 \pm 9.54$ \\
\hline 6 & 55 & 0 & 7 & 0 & $3.25 \pm 0.00$ & $634.77 \pm 13.63$ & $805.37 \pm 24.37$ \\
\hline 7 & 80 & 1 & 4 & -1 & $2.76 \pm 0.00$ & $656.96 \pm 17.19$ & $801.75 \pm 0.00$ \\
\hline 8 & 55 & 0 & 7 & 0 & $3.24 \pm 0.01$ & $627.69 \pm 29.56$ & $805.37 \pm 24.37$ \\
\hline 9 & 80 & 1 & 10 & 1 & $2.48 \pm 0.01$ & $579.04 \pm 18.63$ & $774.76 \pm 0.00$ \\
\hline 10 & 30 & -1 & 7 & 0 & $3.10 \pm 0.00$ & $671.65 \pm 18.59$ & $823.69 \pm 59.77$ \\
\hline 11 & 55 & 0 & 7 & 0 & $3.23 \pm 0.02$ & $619.25 \pm 0.44$ & $788.14 \pm 0.00$ \\
\hline 12 & 80 & 1 & 7 & 0 & $2.91 \pm 0.02$ & $598.94 \pm 4.42$ & $778.15 \pm 14.13$ \\
\hline 13 & 30 & -1 & 10 & 1 & $2.74 \pm 0.02$ & $647.90 \pm 26.09$ & $788.14 \pm 76.35$ \\
\hline
\end{tabular}

TABLE 2. Model equations fitted for cinnamaldehyde yield (CY), TPC and TEAC prediction data for ceylon cinnamon extraction

\begin{tabular}{|c|c|c|c|c|}
\hline Responses & Model Equation & $\begin{array}{c}\text { Model } \\
\text { Significant }\end{array}$ & Lack-of-fit Test & $\mathrm{R}^{2}$ \\
\hline & Actual Equation & $\begin{array}{c}<0.0001 \\
\text { (Significant) }\end{array}$ & $\begin{array}{c}0.751 \text { (not } \\
\text { significant) }\end{array}$ & 0.9981 \\
\hline \multirow[t]{5}{*}{ CY } & $\begin{array}{l}+0.63792+0.043665 * \text { temperature }+0.46026 \\
\text { extraction time }-3.90897 \mathrm{E}-004 * \text { temperature }^{2} \\
-0.032701 * \text { extraction time }{ }^{2}-6.00000 \mathrm{E}-004 * \\
\text { temperature } * \text { extraction time }\end{array}$ & $*$ & & $\begin{array}{c}\text { Adjusted } \\
0.9967 \\
\text { Predicted } \\
0.9935\end{array}$ \\
\hline & Coded Equation & & & \\
\hline & $\begin{array}{l}+3.25-0.088 \mathrm{X}_{1}-0.092 \mathrm{X}_{2}-0.24 \mathrm{X}_{11}-0.29 \mathrm{X}_{22}- \\
0.045 \mathrm{X}_{12}\end{array}$ & & & \\
\hline & $\underline{\text { Actual Equation }}$ & $\begin{array}{c}<0.0001 \\
\text { (Significant) }\end{array}$ & $\begin{array}{c}0.058 \text { not } \\
\text { significant) }\end{array}$ & 0.8576 \\
\hline & $\begin{array}{l}+780.22605-1.14028 * \text { temperature }-12.02546 * \\
\text { extraction time }\end{array}$ & & & $\begin{array}{c}\text { Adjusted } \\
0.8292\end{array}$ \\
\hline \multirow[t]{3}{*}{$\mathrm{TPC}$} & $\underline{\text { Coded Equation }}$ & & & $\begin{array}{c}\text { Predicted } \\
0.6864\end{array}$ \\
\hline & $+633.33-28.51 * X_{1}-36.08 * X_{2}$ & & & \\
\hline & $\underline{\text { Actual Equation }}$ & $\begin{array}{c}0.0002 \\
\text { (Significant) }\end{array}$ & $\begin{array}{l}0.637 \text { (not } \\
\text { significant) }\end{array}$ & 0.8174 \\
\hline \multirow[t]{3}{*}{ TEAC } & $\begin{array}{l}+870.98321-0.55538 * \text { temperature }-6.20968 * \\
\text { extraction time }\end{array}$ & & & $\begin{array}{c}\text { Adjusted } \\
0.7809\end{array}$ \\
\hline & $\underline{\text { Coded Equation }}$ & & & \\
\hline & $+796.97-13.88 * X_{1}-18.63 * X_{2}$ & & & $\begin{array}{c}\text { Predicted } \\
0.6937\end{array}$ \\
\hline
\end{tabular}


TABLE 3. Analysis of coefficient for coded model used to fit cinnamaldehyde yield (CY), TPC, and TEAC ceylon cinnamon extraction

\begin{tabular}{|c|c|c|c|c|c|c|c|c|c|}
\hline & \multicolumn{3}{|c|}{ Cinnamaldehyde yield $(\mathrm{mg} / \mathrm{g})$} & \multicolumn{3}{|c|}{ TPC (mg GAE/g) } & \multicolumn{3}{|c|}{ TEAC $(\mu \mathrm{mol} \mathrm{TE} / \mathrm{g})$} \\
\hline & Coefficient & $\mathrm{F}$ & Prob $<F$ & Coefficient & $\mathrm{F}$ & Prob $<$ F & Coefficient & $\mathrm{F}$ & Prob $<F$ \\
\hline \multicolumn{10}{|l|}{ Independent } \\
\hline \multicolumn{10}{|l|}{ variables } \\
\hline $\mathrm{X}_{1}$-temperature & -0.088 & 222.92 & $<0.0001$ & -28.51 & 23.16 & 0.0007 & -13.88 & 15.99 & 0.0025 \\
\hline $\begin{array}{l}\mathrm{X}_{2-}^{-} \\
\text {extraction time }\end{array}$ & -0.092 & 240.06 & $<0.0001$ & -36.08 & 37.09 & 0.0001 & -18.63 & 28.78 & 0.0003 \\
\hline \multicolumn{10}{|l|}{ Interaction } \\
\hline$X_{11}$ & -0.24 & 784.94 & $<0.0001$ & - & - & - & - & - & - \\
\hline$X_{22}$ & -0.29 & 1139.11 & $<0.0001$ & - & - & - & - & - & - \\
\hline $\mathrm{X}_{12}$ & -0.045 & 38.57 & 0.0004 & - & - & - & - & - & - \\
\hline
\end{tabular}

TABLE 4. Optimization paramater predicted and verification responses result

\begin{tabular}{|c|c|c|c|c|c|c|}
\hline Parameters & Goal & $\begin{array}{l}\text { Lower } \\
\text { Limit }\end{array}$ & $\begin{array}{l}\text { Upper } \\
\text { Limit }\end{array}$ & & & \\
\hline Temperature $\left({ }^{\circ} \mathrm{C}\right)$ & is in range & 30 & 80 & & & \\
\hline Extraction time $(\mathrm{h})$ & is in range & 4 & 10 & & & \\
\hline $\mathrm{CY}(\mathrm{mg} / \mathrm{g})$ & maximize & 2.48 & 3.27 & & & \\
\hline $\begin{array}{c}\text { TPC } \\
\text { (mg GAE/g) }\end{array}$ & maximize & 570.40 & 686.44 & & & \\
\hline $\begin{array}{c}\text { TEAC } \\
(\mu \mathrm{mol} \mathrm{TE} / \mathrm{g})\end{array}$ & maximize & 772.31 & 826.14 & & & \\
\hline Solutions & Temperature & Extraction time & $\mathrm{CY}$ & ТPC & TEAC & Desirability \\
\hline Predicted & 37 & 5 & 3.05 & 682.17 & 821.57 & 0.859 \\
\hline Verification & 37 & 5 & $3.11 \pm 0.71$ & $682.66 \pm 54.85$ & $817.89 \pm 9.03$ & \\
\hline RMSD & & & 0.03 & 0.17 & 0.54 & \\
\hline
\end{tabular}

\section{CONCLUSION}

Analysis of variance (ANOVA) of response surface methodology (RSM) showed that the quadratic model and linear model were fit for cinnamaldehyde yield, TPC, and TEAC responses, respectively. The optimal condition for maximum cinnamaldehyde yield, TPC, and 
TEAC were $37{ }^{\circ} \mathrm{C}$ at $5 \mathrm{~h}$ extraction time with predicted cinnamaldehyde yield of $3.05 \mathrm{mg} / \mathrm{g}$, TPC of $682.17 \mathrm{mg}$ GAE/g, and TEAC of $821.57 \mu \mathrm{mol} \mathrm{TE} / \mathrm{g}$, respectively. The verification value obtained for the cinnamaldehyde yield, TPC, and TEAC under the optimal condition were $3.11 \pm 0.71 \mathrm{mg} / \mathrm{g}, 682.66 \pm 54.85 \mathrm{mg} \mathrm{GAE} / \mathrm{g}$, and $817.89 \pm 9.03 \mu \mathrm{mol} \mathrm{TE} / \mathrm{g}$. Cinnamaldehyde yield, TPC, and TEAC were significantly $(p<0.05)$ influence by temperature and extraction time with negative coefficient. There were also significant $(p<0.05)$ interaction between temperature and extraction time towards cinnamaldehyde yield. The models were fit for all responses and the model were able to be used in determining the optimal condition for cinnamaldehyde extraction with maximum antioxidant activity.

\section{ACKNOWLEDGEMENTS}

The authors would like to thank Universiti Kebangsaan Malaysia for providing financial support to this project under grant No. GUP-2017-014.

\section{REFERENCES}

Abed, K.M., Kurji, B.M. \& Abdul-Majeed, B.A. 2015. Extraction and modelling of oil from eucalyptus camadulensis by organic solvent. Journal of Materials Science and Chemical Engineering 3(08): 35-42.

Ashakirin, S.N., Tripathy, M., Patil, U.K. \& Majeed, A.B.A. 2017. Chemistry and bioactivity of cinnamaldehyde: A natural molecule of medicinal importance. International of Pharmaceutical Sciences and Research 8(6): 2333-2340.

Baba, W.N., Rashid, I., Shah, A., Ahmad, M., Gani, A., Masoodi, F.A. \& Wani, S.M. 2016. Effect of microwave roasting on antioxidant and anticancerous activities of barley flour. Journal of the Saudi Society of Agricultural Sciences 15(1): 12-19.

Dvorackova, E., Snoblova, M., Chromcova, L. \& Hrdlicka, P. 2015. Effects of extraction methods on the phenolic compounds contents and antioxidant capacities of cinnamon extracts. Food Science and Biotechnology 24(4): 1201-1207.

Haslaniza, H., Maskat, M.Y., Aida, W.W., Mamot, S. \& Saadiah, I. 2013. Optimization of enzymatic hydrolysis of cockle (Anadara granosa) meat wash water precipitate for the development of seafood flavor. International Food Research Journal 20(6): 3053.

Jiao, L., Zhang, X., Huang, L., Gong, H., Cheng, B., Sun, Y. \& Huang, K. 2013. Proanthocyanidins are the major antidiabetic components of cinnamon water extract. Food and Chemical Toxicology 56: 398-405.

Jayaprakasha, G.K., Negi, P.S., Jena, B.S. \& Rao, L.J.M. 2007. Antioxidant and antimutagenic activities of Cinnamomum zeylanicum fruit extracts. J. Food Compos. Anal. 20: 330336.

Kim, J.H. 2017. Extraction time and temperature affect the extraction efficiencies of coumarin and phenylpropanoids from Cinnamomum cassia bark using a microwaveassisted extraction method. Journal of Chromatography B 1063: 196-203.
Kim, A.N., Kim, H.J., Chun, J., Heo, H.J., Kerr, W.L. \& Choi, S.G. 2018. Degradation kinetics of phenolic content and antioxidant activity of hardy kiwifruit (Actinidia arguta) puree at different storage temperatures. LWT 89: 535-541.

Khuri, A.I. \& Cornell, J.A. 2018. Response Surfaces: Designs and Analyses. England: Routledge.

Lee, H.G., Jo, Y., Ameer, K. \& Kwon, J.H. 2018. Optimization of green extraction methods for cinnamic acid and cinnamaldehyde from Cinnamon (Cinnamomum cassia) by response surface methodology. Food Science and Biotechnology 27(6): 1607-1617.

Momtaz, S., Hassani, S., Khan, F., Ziaee, M. \& Abdollahi, M. 2018. Cinnamon, a promising prospect towards Alzheimer's disease. Pharmacological Research 130: 241258.

Mathew, S. \& Abraham, T.E. 2006. In vitro antioxidant activity and scavenging effects of Cinnamomum verum leaf extract assayed by different methodologies. Food Chem. Toxicol. 44: 198-206.

Nandam, S.S., Prakash, D.V.S. \& Vangalapati, M. 2012. Optimization of physico-chemical parameters for the extraction of phenolic components from cinnamon species. Journal of Academia and Industrial Research 1(4): 183185.

Peterson, D.W., George, R.C., Scaramozzino, F., LaPointe, N.E., Anderson, R.A., Graves, D.J. \& Lew, J. 2009. Cinnamon extract inhibits tau aggregation associated with Alzheimer's disease in vitro. Journal of Alzheimer's Disease 17(3): 585-597.

Piñeiro, G., Perelman, S., Guerschman, J.P. \& Paruelo, J.M. 2008. How to evaluate models: Observed vs. predicted or predicted vs. observed? Ecological Modelling 216(3-4): 316-322.

Singletary, K. 2008. Cinnamon: Overview of health benefits. Nutrition Today 43(6): 263-266.

Sembiring, E.N., Elya, B. \& Sauriasari, R. 2018. Phytochemical screening, total flavonoid and total phenolic content and antioxidant activity of different parts of Caesalpinia bonduc (L.) Roxb. Pharmacognosy Journal 10(1): 123-127.

Suryanti, V., Wibowo, F.R., Khotijah, S. \& Andalucki, N. 2018. Antioxidant activities of cinnamaldehyde derivatives. IOP Conference Series: Materials Science and Engineering 333(1): 012077.

Utchariyakiat, I., Surassmo, S., Jaturanpinyo, M., Khuntayaporn, P. \& Chomnawang, M.T. 2016. Efficacy of cinnamon bark oil and cinnamaldehyde on anti-multidrug resistant Pseudomonas aeruginosa and the synergistic effects in combination with other antimicrobial agents. BMC Complementary and Alternative Medicine 16(1): 158.

Wardatun, S., Rustiani, E., Alfiani, N. \& Rissani, D. 2017. Study effect type of extraction method and type of solvent to cinnamaldehyde and trans-cinnamic acid dry extract cinnamon (Cinnamomum burmanii [Nees \& T, Nees] Blume). Journal of Young Pharmacists 9(1): S49- S51.

Wang, Y.H., Avula, B., Nanayakkara, N.P.D., Zhao, J. \& Khan, I.A. 2013. Cassia cinnamon as a source of coumarin in cinnamon-flavored food and food supplements in the United States. J. Agr. Food Chem. 61: 4470-4476.

Yang, C.H., Li, R.X. \& Chuang, L.Y. 2012. Antioxidant activity of various parts of Cinnamomum cassia extracted with different extraction methods. Molecules 17(6): 7294-7304. 
Zhen, H., Shen, X., Bu, G. \& Luo, Y. 2008. Effect of pH, temperature and enzyme-to-substrate ratio on the antigenicity of whey protein hydrolysates prepared by Alcalase. International Dairy Journal 18: 1028-1033.

Zetty Shafiqa Othman \& Nur Hasyareeda Hassan* Department of Chemical Sciences

Faculty of Science and Technology

Universiti Kebangsaan Malaysia

43600 UKM Bangi, Selangor Darul Ehsan

Malaysia
Mohamad Yusof Maskat

Department of Food Sciences

Faculty of Science and Technology

Universiti Kebangsaan Malaysia

43600 UKM Bangi, Selangor Darul Ehsan

Malaysia

*Corresponding author; email: syareeda@ukm.edu.my

Received: 3 October 2019

Accepted: 19 January 2020 